\title{
Analisis Kemacetan Dan Perkiraan Tingkat Pelayanan Jalan Pada Masa Mendatang (Studi Kasus Jalan Raya Sawangan Depok)
}

\section{(Traffic Jam Analysis and Prediction of Future Road Service Level (Case Study of Jalan Raya Sawangan Depok)}

\author{
Rangga Apriliyanto ${ }^{1}$, dan Tri Sudibyo ${ }^{1 *}$ \\ ${ }^{1}$ Departemen Teknik Sipil dan Lingkungan IPB, Kampus IPB Dramaga, Bogor 16880 \\ *Penulis korespondensi: tri.sudibyo@apps.ipb.ac.id
}

\begin{abstract}
The road growth relatively smaller than traffic volume growth caused decreasing of the road service level. The purpose of the research were indentified performance existing geometry condition and traffic condition of Jalan Raya Sawangan as well as to formulate program to resolve traffic jam. Existing condition performance of Jalan Raya Sawangan on segment 1 as well as 2 were classified as $F$ and $E$ whereas the non-signal intersection performance of the road was $F$. The geometry improvement was chosed to resolve traffic jam so the service level for the next 15 years could be calassified as D. Improvement of intersection performance was conducted by changing non-signal intersection becomed signal and changing the signal intersection becomed interchange. Signal intersection was only able to receive traffic load for 10 years thus re-upgrading was required to match with the planned target by changing the intersection to interchange. Service level of interchange obtained level A because suitable with the requirement.
\end{abstract}

Keywords: geometry condition, service level, traffic growth, traffic jam

\section{PENDAHULUAN}

Pertumbuhan jumlah kendaraan di kota Depok cenderung lebih tinggi dibanding dengan pertumbuhan ruas jalan sehingga tingkat pelayanan jalan maupun simpang menurun di tiap tahunnya. Jalan raya merupakan infrastruktur yang salah satu fungsinya penunjang perekonomian masyarakat sehingga perlu diperhatikan kualitas kinerja dari jalan tersebut. Oleh karena itu, pembangunan jalan-jalan baru, pengawasan dan pemeliharaan terhadap jalan-jalan yang sudah ada harus tetap dilaksanakan agar tidak mengalami kerusakan sebelum umur rencana yang diperhitungkan tercapai (Abubakar et al. 1995).

Kemacetan yang terjadi dapat merugikan aktivitas perekonomian warga kota Depok (Sinulingga 1999). Kemacetan lalu lintas merupakan permasalahan yang 85 dapat merugikan pengguna jalan dalam kenyamanan berkendara, kelelahan perjalanan, pemborosan waktu dan materi. Selain itu, kemacetan lalu lintas juga berpotensi terjadinya pelanggaran dan kecelakaan lalu lintas oleh pengguna jalan. Oleh karena itu, diperlukan analisis kemacetan untuk mengetahui kinerja jalan dan faktor-faktor yang menyebabkan kemacetan tersebut. Hasil analisis tersebut dapat digunakan dalam perencanaan jalan lalu lintas untuk masa mendatang sehingga dapat mengurangi dampak dari kemacetan dalam jangka waktu yang panjang.

Menurut Sukirman (1999) faktor pertumbuhan jumlah kendaraan dapat diperoleh dari hasil analisis data lalu lintas dan perkembangan penduduk. Berdasarkan analisis yang dilakukan dalam mengetahui kinerja jalan, dapat dilakukan perencanaan rekayasa lalu lintas yang sesuai dengan 
kebutuhan dan kondisi lapang (Putri 2014). Pada penelitian ini dilakukan analisis kinerja jalan dari kondisi eksisting berdasarkan nilai volume lalu lintas jam puncak. Selain itu, dilakukan perencanaan serta rekayasa lalu lintas untuk memperbaiki kondisi geometri maupun rekayasa lainnya yang bertujuan meningkatkan tingkat pelayanan jalan serta mempertahankan tingkat pelayanan tersebut hingga masa mendatang atau selama umur rencana.

\section{METODE PENELITIAN}

Penelitian dilakukan selama enam bulan, dari bulan Februari hingga Juli 2018. Survei lapangan untuk mendapatkan jumlah kendaraan, kapasitas jalan dan volume kendaraan dilakukan di pos pengamatan yang berada di segmen ruas Jln. Sawangan Raya dan simpang Jln. Pramukan Raya Depok. Petal lokasi penelitian disajikan pada Gambar 1.

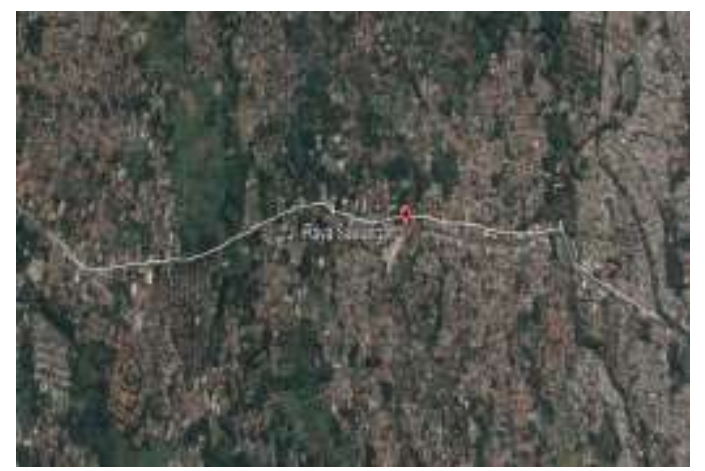

Gambar 1 Peta lokasi penelitian

Pengumpulan data volume lalu lintas pada garis pengamatan dilakukan dengan cara mencatat semua kendaraan yang melewati suatu garis injak melintang pada pos pengamatan. Pelaksanaan survei kecepatan dilakukan dengan menggunakan stopwatch, waktu tempuh kendaraan dihitung pada jarak yang telah ditentukan, yaitu 20 meter. Pencatatan dilakukan untuk setiap waktu 15 menitan setiap jam pengamatan.

Pengumpulan data volume lalu lintas ruas Jalan Raya Sawangan dilakukan pada hari Rabu dan Sabtu, dari pukul 06.30-08.30 (pagi), 12.30-14.30 (siang), dan pukul 16.0018.00 (sore). Analisis kinerja ruas jalan pada ruas jalan menggunakan pedoman MKJI dan pemodelan matematis Greenshield sedangkan simpang hanya menggunakan MKJI 1997. Alur pelaksanaan penelitian digambarkan pada skema Gambar 2.

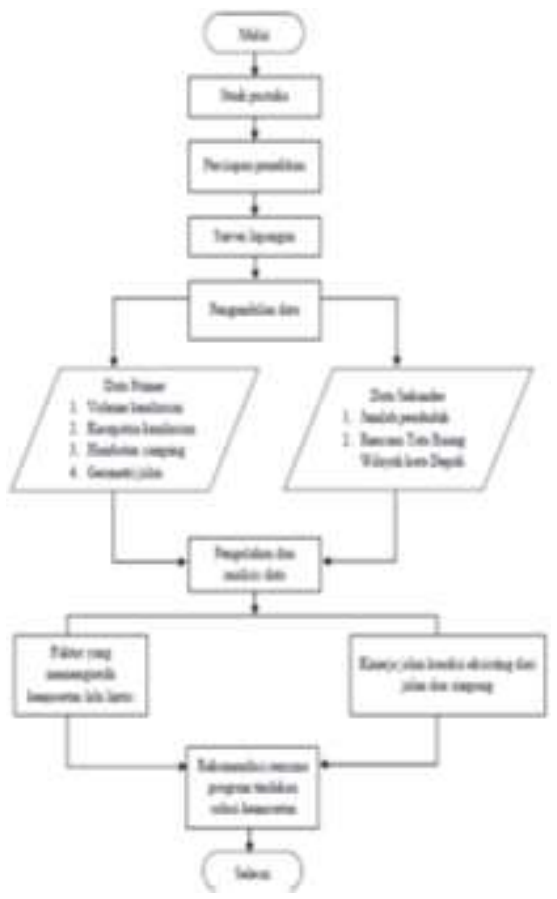

Gambar 2 Diagram alir penelitian

\section{HASIL DAN PEMBAHASAN}

\section{Kinerja ruas jalan segmen 1}

a) Analisis menggunakan perhitungan Manual Kapasitas Jalan Indonesia 1997 Hasil perhitungan untuk mengetahui kinerja ruas jalan berdasarkan perhitungan yang terdapat pada Manual Kapasitas Jalan Indonesia 1997 seperti di sajikan pada Tabel 1 .

Tabel I Kinerja ruas jalan segnen I kondisi eksisting menggunakan MKJI

\begin{tabular}{lccccc}
$\begin{array}{c}\text { Titik } \\
\text { pengamatan }\end{array}$ & Kapasitas & $\begin{array}{c}\text { Arus lalu } \\
\text { lintas } \\
\text { (smp/jam) } \\
\text { (smp/jam) }\end{array}$ & $\begin{array}{c}\text { Derajat } \\
\text { kejenuhan } \\
\text { (V/C) }\end{array}$ & Kecepatan & $\begin{array}{c}\text { Tingkat } \\
\text { Pelayanan }\end{array}$ \\
\hline Rabu & 2.912 & 2.671 & 0,92 & 28 & F \\
Sabtu & 2.912 & 2.534 & 0,87 & 30 & E \\
\hline
\end{tabular}

Tabel 1 menunjukkan kecepatan yang terhitung berdasarkan metode MKJI dari masing-masing hari ialah 28 dan $30 \mathrm{~km} / \mathrm{jam}$ sehingga berdasarkan tingkat pelayanan yang terdapat pada Peraturan Menteri Perhubungan Republik Indonesia Nomor : 
PM 96 tahun 2015, masing-masing tingkat pelayanan pada hari kerja dan hari libur ialah E dan F.

b) Analisis menggunakan pemodelan matematis Greenshield

Pengembangan model korelasi ini berdasarkan data-data primer, yaitu data volume lalu lintas dan kecepatan kendaraan yang sudah didapatkan. Hal yang cukup penting dan perlu diperhatikan adalah model korelasi yang akan dibangun akan valid jika dan hanya jika survei dilakukan pada ruas jalan yang sama dan periode waktu yang sama juga.Terdapat empat langah utama dalam proses membangun model korelasi Q - V - K, yaitu survei dan pengambilan data, proses validasi data, pengembangan model korelasi dan analisa model korelasi. Tahap terakhir dari pemodelan ini ialah untuk mendapatkan parameter-parameter pengukuran kinerja jalan seperti kapasitas maksimum $\left(\mathrm{Qm}_{\mathrm{m}}\right.$, kecepatan pada saat arus maksimum $\left(\mathrm{V}_{\mathrm{m}}\right)$ dan kerapatan pada saat arus maksimum $\left(\mathrm{Km}_{\mathrm{m}}\right.$.

Tujuan dari pengembangan model korelasi $\mathrm{Q}-\mathrm{V}-\mathrm{K}$ ini selain untuk mengetahui seberapa besar hubungan antara masing-masing variabel lalu lintas yang ada. Hasil pemodelan korelasi $\mathrm{Q}-\mathrm{V}-\mathrm{K}$ dari hasil data pengamatan pada jam puncak pagi seperti disajikan pada Gambar 3, 4 dan 5.

Proses validasi data perlu dilakukan pada model ini, persamaan korelasi yang digunakan sebagai dasar ialah persamaan yang mempunyai nilai $\mathrm{R}^{2}$ terbesar, yaitu persamaan korelasi $\mathrm{V}-\mathrm{K}$ dengan nilai $\mathrm{R}^{2}$ sebesar 0,9823. Nilai $x$ (kerapatan kendaraan $\mathrm{x})$ yang akan digunakan yaitu 0 - 200 dengan tujuan untuk mendapatkan berapa nilai arus lalu lintas (Q) yang terjadi saat grafik tersebut kembali atau mendekati nilai 0 (nol).

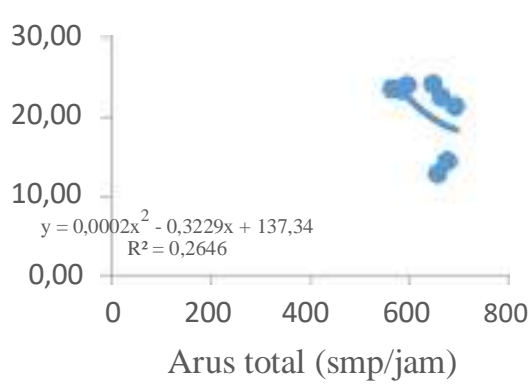

Gambar 2 Hubungan antara arus total dan kecepatan pada segmen 1

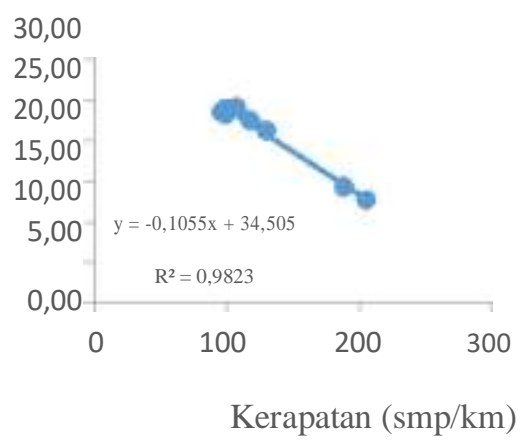

Gambar 3 Hubungan antara kerapatan dan kecepatan pada segmen 1

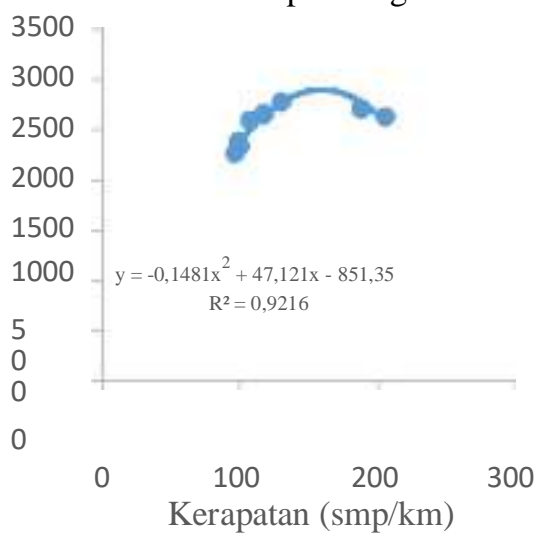

Gambar 4 Hubungan antara kerapatan dan arus total pada segmen 1 
Nilai $\mathrm{x}$ tersebut diinput ke dalam persamaan $y=-0,1481 x^{2}+47,121 x-851,35$ (persamaan korelasi Q $-\mathrm{K}$ ) sehingga didapatkan nilai y (arus lalu lintas) untuk setiap nilai $x$ tersebut. Selanjutnya, nilai-nilai y (arus lalu lntas) yang sudah didapatkan diasumsikan dengan nilai $\mathrm{x}$ untuk persamaan $\mathrm{y}=-0,1055 \mathrm{x}+34,505$ (persamaan korelasi $\mathrm{V}$ - K) dan akan didapat nilai y yang baru (kecepatan) untuk setiap nilai $\mathrm{x}$ (kerapatan) yang ada.Tahap selanjutnya ialah validasi data dengan tujuan utama adalah untuk mengetahui apakah persamaan korelasi yang sudah didapatkan/dikembangkan cukup valid jika kita memasukkan sembarang nilai $\mathrm{x}$ untuk setiap persamaan korelasi yang ada.

Berdasarkan validasi tersebut, didapatkan nilai arus lalu lintas maksimum (kapasitas jalan) sebesar 2.897 smp/jam, kecepatan bebas kendaraan pada saat arus maksimum adalah $17,73 \mathrm{~km} / \mathrm{jam}$ dengan kerapatan kendaraan pada saat arus maksimum adalah $159 \mathrm{smp} / \mathrm{km}$ dan rentang jarak adalah $0,006121 \mathrm{~km} / \mathrm{smp}$. Hasil analisis berdasarkan model korelasi seperti disajikan pada Tabel 2.

Tabel 2 Kinerja ruas jalan segmen 1 kondisi eksisting dengan pemodelan Greenshield

\begin{tabular}{lccccc}
\hline $\begin{array}{c}\text { Hari } \\
\text { pengamatan }\end{array}$ & Kapasitas & $\begin{array}{c}\text { Arus lalu } \\
\text { lintas } \\
(\mathrm{smp} / \mathrm{jam})\end{array}$ & $\begin{array}{c}\text { Derajat } \\
\text { kejenuhan } \\
(\mathrm{V} / \mathrm{j} / \mathrm{C})\end{array}$ & $\begin{array}{c}\text { Kecepatan }) \\
\begin{array}{c}\text { Tingkat } \\
\text { Pelayanan }\end{array}\end{array}$ \\
\hline Rabu & 2.897 & 2.671 & 0,93 & 17,73 & $\mathrm{~F}$ \\
Sabtu & 2.667 & 2.534 & 0,88 & 23,97 & $\mathrm{~F}$ \\
\hline
\end{tabular}

\section{Kinerja ruas jalan segmen 2}

a) Analisis menggunakan Manual Kapasitas Jalan Indonesia

Hasil perhitungan untuk mengetahui kinerja ruas jalan berdasarkan perhitungan

dari yang terdapat pada Manual Kapasitas Jalan Indonesia 1997 disajikan pada Tabel 3. Kecepatan yang terhitung berdasarkan metode MKJI dari masing-masing hari ialah 32,5 dan $34 \mathrm{~km} / \mathrm{jam}$ sehingga berdasarkan tingkat pelayanan yang terdapat pada Peraturan Menteri Perhubungan Republik Indonesia Nomor : PM 96 tahun 2015, masing-masing tingkat pelayanan pada hari kerja dan hari libur ialah $\mathrm{E}$.

b) Analisis menggunakan pemodelan matematis Greenshield

Hasil pemodelan korelasi $\mathrm{Q}-\mathrm{V}-\mathrm{K}$ dari hasil data pengamatan pada jam puncak pagi seperti disajikan pada Gambar 5, 6, dan 7

Tabel 3 Kinerja ruas jalan segmen 2 kondisi eksisting menggunakan MKJI

\begin{tabular}{lccccc}
\hline $\begin{array}{c}\text { Titik } \\
\text { pengamatan }\end{array}$ & Kapasitas & $\begin{array}{c}\text { Arus lalu } \\
\text { lintas } \\
(\mathrm{smp} / \mathrm{jam})\end{array}$ & $\begin{array}{c}\text { Derajat } \\
\text { kejenuhan } \\
(\mathrm{V} / \mathrm{C})\end{array}$ & Kecepatan & $\begin{array}{c}\text { Tingkat } \\
\text { Pelayanan } \\
(\mathrm{km} / \mathrm{jam})\end{array}$ \\
\hline Rabu & 3.014 & 2.035 & 0.68 & 32,5 & $\mathrm{E}$ \\
Sabtu & 3.014 & 1.762 & 0,58 & 34,0 & $\mathrm{E}$ \\
\hline
\end{tabular}




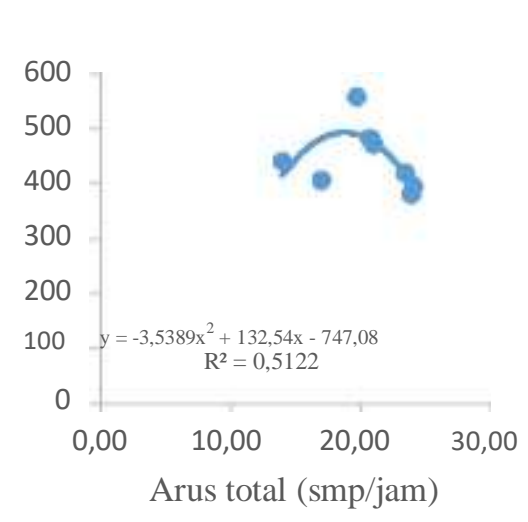

Gambar 5 Hubungan antara arus total dan kecepatan

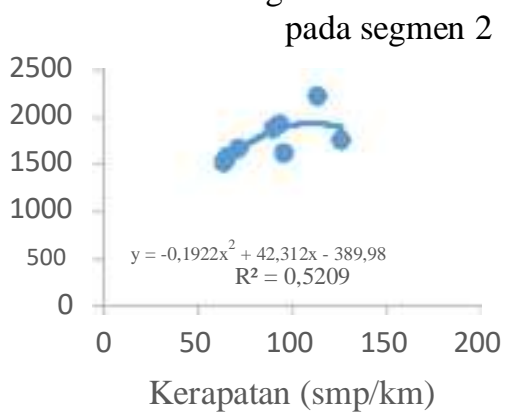

Gambar 6 Hubungan antara kerapatan dan kecepatan pada segmen 2

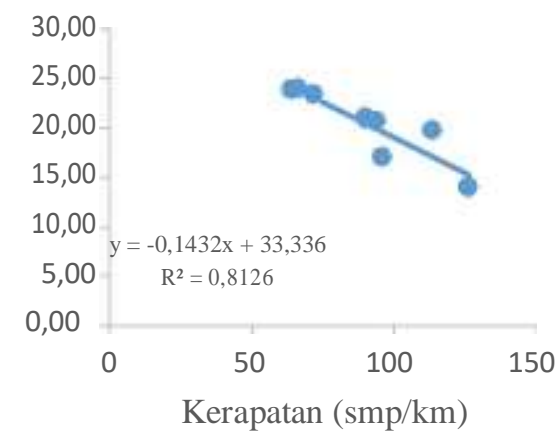

Gambar 7 Hubungan antara kerapatan dan arus total pada segmen 2

Berdasarkan proses validasi, didapatkan nilai arus lalu lintas maksimum (kapasitas jalan) sebesar $1.938 \mathrm{smp} / \mathrm{jam}$, kecepatan bebas kendaraan pada saat arus maksimum adalah $17,584 \mathrm{~km} / \mathrm{jam}$ dengan kerapatan kendaraan pada saat arus maksimum adalah $110 \mathrm{smp} / \mathrm{km}$ dan rentang jarak adalah $0,00907 \mathrm{~km} / \mathrm{smp}$. Hasil analisis berdasarkan model korelasi seperti disajikan pada Tabel 4.

Tabel 4 Kinerja ruas jalan segmen 2 kondisi eksisting dengan pemodelan Greenshield

\begin{tabular}{lccccc}
\hline $\begin{array}{c}\text { Hari } \\
\text { pengamatan }\end{array}$ & Kapasitas & $\begin{array}{c}\text { Arus lalu } \\
\text { lintas } \\
(\mathrm{smp} / \mathrm{jam})\end{array}$ & $\begin{array}{c}\text { Derajat } \\
\text { kejenuhan } \\
(\mathrm{s} / \mathrm{jam})\end{array}$ & $\begin{array}{c}\text { Kecepatan } \\
(\mathrm{km} / \mathrm{jam})\end{array}$ & $\begin{array}{c}\text { Tingkat } \\
\text { Pelayanan }\end{array}$ \\
\hline Rabu & 1.938 & 2.194 & 0,93 & 17,72 & $\mathrm{E}$ \\
Sabtu & 2.002 & 1.762 & 0,88 & 21,51 & $\mathrm{E}$ \\
\hline
\end{tabular}

\section{Kinerja Simpang Tak Bersinyal Kondisi Eksisting}

Pada penelitian ini untuk mengetahui kinerja simpang tak bersinyal pada kondisi eksisting hanya digunakan satu metode, yaitu perhitungan dengan menggunakan perumusan dari Manual Kapasitas Jalan Indonesia 1997. Nilai kapasitas dari metode tersebut digunakan dalam menggambarkan kondisi lapang. Hasil analisis kinerja simpang pada hari kerja dan libur seperti disajikan pada Tabel 5.

Tabel 5 Hasil analisis kinerja simpang pada hari kerja dan hari libur

\begin{tabular}{lccccc}
\hline $\begin{array}{c}\text { Titik } \\
\text { pengamatan }\end{array}$ & $\begin{array}{c}\text { Kapasitas } \\
(\mathrm{smp} / \mathrm{jam})\end{array}$ & $\begin{array}{c}\text { Arus } \\
(\mathrm{smp} / \mathrm{jam})\end{array}$ & $\begin{array}{c}\text { Derajat } \\
\text { kejenuhan }\end{array}$ & Tundaan & $\begin{array}{c}\text { Tingkat } \\
\text { Pelayanan }\end{array}$ \\
\hline \multirow{3}{*}{ Sabtu } & 3.446 & 6.531 & 1,896 & $-3,52$ & $\mathrm{~F}$ \\
& 3.350 & 5.334 & 1,592 & $-15,45$ & $\mathrm{~F}$ \\
\hline
\end{tabular}


Tabel 5 menunjukkan bahwa tundaan yang dihasilkan berdasarkan formulir simpang pada MKJI dari masingmasing hari kerja maupun libur adalah 3,52 dan $-15,45$. Nilai negatif pada tundaan tersebut disebabkan kondisi lapang yang terjadi memiliki nilai derajat kejenuhan lebih dari 1 . Kondisi tersebut tidak dapat didefinisi dengan baik berdasarkan perumusan yang terdapat di MKJI. Ketidakmampuan simpang dalam menerima beban lalu lintas menyebabkan tundaan yang parah sehingga terjadinya antrian panjang dan kemacetan.

Tundaan yang didapat dapat disimpulkan tingkat pelayanan-nya sehingga berdasarkan tingkat layanan yang terdapat pada Peraturan Menteri Perhubungan
Republik Indonesia Nomor : PM 96 tahun 2015, masing-masing tingkat pelayanan pada hari kerja dan hari libur ialah $\mathrm{F}$. Tingkat pelayanan tersebut menunjukkan jalan cenderung buruk dalam pelayanannya sehingga diperlukan solusi untuk meningkatkan kinerja jalan yang dapat dipertahankan hingga masa mendatang.

\section{Perbaikan Geometri Jalan pada Jalan Segmen 1}

Perencanaan berlaku untuk umur rencana selama 6 tahun. Rekayasa ini diharapkan sebagai program tindakan yang dapat direkomendasikan untuk mengatasi kemacetan. Hasil rekayasa geometri jalan disajikan pada Tabel 6.

Tabel 6 Kinerja ruas jalan segmen 1 di tahun 2018 hingga tahun 2033

\begin{tabular}{|c|c|c|c|c|c|c|c|}
\hline Tahun & $\begin{array}{l}\text { Kondisi } \\
\text { geometri }\end{array}$ & $\begin{array}{l}\text { Lebar } \\
\text { lajur } \\
(\mathrm{m})\end{array}$ & $\begin{array}{l}\text { Kapasitas } \\
\text { (smp/jam) }\end{array}$ & $\begin{array}{c}\text { Arus lalu } \\
\text { lintas } \\
\text { (smp/jam) }\end{array}$ & $\begin{array}{c}\text { Derajat } \\
\text { kejenuhan } \\
(\mathrm{Q} / \mathrm{C})\end{array}$ & $\begin{array}{l}\text { Kecepatan } \\
(\mathrm{km} / \mathrm{jam})\end{array}$ & $\begin{array}{c}\text { Tingkat } \\
\text { Pelayanan }\end{array}$ \\
\hline 2018 & $2 / 2 \mathrm{UD}$ & 4,2 & 2.912 & 2.671 & 0,92 & 28 & $\mathrm{~F}$ \\
\hline 2019 & & & 5.425 & 2.765 & 0,51 & 46,00 & $E$ \\
\hline 2020 & & & 5.425 & 2.861 & 0,53 & 45,73 & $\mathrm{E}$ \\
\hline 2021 & $4 / 2$ UD & 3 & 5.425 & 2.962 & 0,55 & 45,46 & $\mathrm{E}$ \\
\hline 2022 & & & 5.425 & 3.065 & 0,56 & 45,19 & $\mathrm{E}$ \\
\hline 2023 & & & 5.425 & 3.173 & 0,58 & 44,50 & $\mathrm{E}$ \\
\hline 2024 & & & 5.914 & 3.284 & 0,56 & 49,50 & $\bar{E}$ \\
\hline 2025 & & & 5.914 & 3.399 & 0,57 & 49,00 & $\mathrm{E}$ \\
\hline 2026 & $4 / 2 \mathrm{UD}$ & 4 & 5.914 & 3.517 & 0,59 & 48,50 & $\mathrm{E}$ \\
\hline 2027 & & & 5.914 & 3.641 & 0,62 & 48,00 & $\mathrm{E}$ \\
\hline 2028 & & & 5.914 & 3.768 & 0,64 & 47,50 & E \\
\hline 2029 & & & 3.486 & 1.745 & 0,50 & 55,00 & $\bar{D}$ \\
\hline 2030 & & & 3.486 & 1.806 & 0,52 & 54,50 & D \\
\hline 2031 & $4 / 2 \mathrm{D}$ & 4 & 3.486 & 1.869 & 0,54 & 54,00 & D \\
\hline 2032 & (Arah 1) & & 3.486 & 1.935 & 0,55 & 53,50 & $\mathrm{D}$ \\
\hline 2033 & & & 3.486 & 2.002 & 0,57 & 53,00 & D \\
\hline 2029 & & & 3.486 & 2.155 & 0,62 & 52,00 & $\bar{D}$ \\
\hline 2030 & & & 3.486 & 2.231 & 0,64 & 51,50 & D \\
\hline 2031 & $4 / 2 \mathrm{D}$ & 4 & 3.486 & 2.309 & 0,66 & 51,00 & D \\
\hline 2032 & (Arah 2) & & 3.486 & 2.390 & 0,69 & 50,50 & $\mathrm{D}$ \\
\hline 2033 & & & 3.486 & 2.473 & 0,71 & 50,00 & $\mathrm{D}$ \\
\hline
\end{tabular}


Berdasarkan pada Tabel 6 menujukkan kinerja ruas jalan pada tahun 2019 hingga tahun 2033, dipilih beberapa rekayasa jalan seperti perbaikan geometri. Lebar jalan pada tahun 2019-2023 atau 5 tahun pertama menjadi $12 \mathrm{~m}$ ( 2 arah) dengan tiap lajur $3 \mathrm{~m}$ sehingga dampak yang terjadi ialah penambahan kapasitas yang awalnya $2.912 \mathrm{smp} / \mathrm{jam}$ menjadi $5.425 \mathrm{smp} . j \mathrm{am}$. Hasil dari rekayasa geometri tersebut meningkatkan nilai kecepatan kendaraan menjadi 46,00 km/jam dan terus menurun seiring bertambahnya arus lalu lintas menjadi $44,50 \mathrm{~km} / \mathrm{jam}$ pada tahun 2023 sehingga berdasarkan nilai kecepatan maka tingkat pelayanan naik ke tingkat $\mathrm{E}$.

Perbaikan di 5 tahun berikutnya pada tahun 2024-2028 dilakukan pelebaran lajur menjadi $4 \mathrm{~m}$ sehingga lebar jalan untuk dua arah ialah $16 \mathrm{~m}$. Hasil dari rekayasa geometri tersebut meningkatkan nilai kecepatan kendaraan menjadi 49,50 km/jam dan terus menurun seiring bertambahnya arus lalu lintas menjadi $47,50 \mathrm{~km} / \mathrm{jam}$ namun tingkat pelayanan jalan masih di tingkat E.

Tahap ketiga dalam rekayasa kondisi geometri untuk 5 tahun berikutnya (20292033) ialah dengan memberikan median pada ruas jalan. Median digunakan sebagai pembatas antara jalur satu dengan jalur lainnya sehingga dalam analisis kinerja ruas jalan ditinjau setiap arahnya. Median meningkatkan nilai kapasitas jalan menjadi $3.486 \mathrm{smp} / \mathrm{jam}$ per arah sehingga jika dijumlahkan nilai kapasitas yang terhitung ialah $6.972 \mathrm{smp} / \mathrm{jam}$. Hasil dari rekayasa geometri tersebut meningkatkan nilai kecepatan kendaraan menjadi 55,00 km/jam dan terus menurun seiring bertambahnya arus lalu lintas menjadi $50,00 \mathrm{~km} / \mathrm{jam}$ di tahun 2033 sehingga tingkat pelayanan naik ke tingkat D. Hasil rekayasa tersebut menunjukkan tingkat pelayanan meningkat dari kondisi eksisting sehingga pada masa mendatang kemacetan lalu lintas kota Depok selama umur rencana dapat dikendalikan.

\section{Perbaikan Geometri Pada Jalan Segmen 2}

Pada penelitian ini untuk mengatasi masalah kemacetan lalu lintas yang terjadi pada jalan segmen 2 dipilih rekayasa geometri jalan berupa pelebaran jalan dan pemberian median sehingga diharapkan dapat meningkatkan nilai kapasitas dari jalan tersebut. Hasil rekayasa geometri jalan seperti terlihat pada Tabel 7.

Tabel 7 menujukkan bahwa kinerja ruas jalan pada tahun 2019 hingga tahun 2033 dengan melakukan beberapa rekayasa geometri seperti pada 5 tahun pertama ruas Jalan Raya Sawangan Segmen 2 dilakukan pelebaran jalan dan menambah jumlah lajur. Lebar jalan pada tahun 2019-2023 atau 5 tahun pertama menjadi $12 \mathrm{~m}$ ( 2 arah) dengan tiap lajur $3 \mathrm{~m}$ sehingga dampak yang terjadi ialah penambahan kapasitas yang awalnya $2.912 \mathrm{smp} / \mathrm{jam}$ menjadi $5.685 \mathrm{smp} / \mathrm{jam}$. Hasil dari rekayasa geometri tersebut meningkatkan nilai kecepatan kendaraan menjadi $49,50 \mathrm{~km} / \mathrm{jam}$ dan terus menurun seiring bertambahnya arus lalu lintas menjadi 47,50 km/jam di tahun 2023 namun berdasarkan Peraturan Menteri Perhubungan Republik Indonesia Nomor : PM 96 tahun 2015 dengan kecepatan kendaraan yang dihasilkan maka tingkat pelayanan jalan tetap di tingkat D.

Perbaikan di 5 tahun berikutnya pada tahun 2024-2028 dilakukan pelebaran lajur menjadi $4 \mathrm{~m}$ sehingga lebar jalan untuk dua arah ialah $16 \mathrm{~m}$. Hasil rekayasa meningkatkan nilai kapasitas jalan menjadi $6.197 \mathrm{smp} / \mathrm{jam}$. Pelebaran lajur memberikan ruang tambahan bagi para pengendara sehingga kecepatan meningkat menjadi $52,00 \mathrm{~km} / \mathrm{jam}$ dan terus menurun seiring bertambahnya arus lalu lintas menjadi 50,00 $\mathrm{km} / \mathrm{jam}$ di tahun 2028. Rekayasa tahap 2 ini belum bisa meningkatkan tingkat pelayanan sehingga tetap di tingkat D. 
Tabel 7 Kinerja ruas jalan segmen 2 di tahun 2018 hingga tahun 2033

\begin{tabular}{|c|c|c|c|c|c|c|c|}
\hline Tahun & $\begin{array}{l}\text { Kondisi } \\
\text { geometri }\end{array}$ & $\begin{array}{c}\text { Lebar } \\
\text { lajur } \\
(\mathrm{m})\end{array}$ & $\begin{array}{l}\text { Kapasitas } \\
\text { (smp/jam) }\end{array}$ & $\begin{array}{c}\text { Arus lalu } \\
\text { lintas } \\
\text { (smp/jam) }\end{array}$ & $\begin{array}{c}\text { Derajat } \\
\text { kejenuhan } \\
(\mathrm{V} / \mathrm{C})\end{array}$ & $\begin{array}{c}\text { Kecepatan } \\
(\mathrm{km} / \mathrm{jam})\end{array}$ & $\begin{array}{c}\text { Tingkat } \\
\text { Pelayanan }\end{array}$ \\
\hline 2018 & $2 / 2 \mathrm{UD}$ & 3.5 & 3.014 & 2.194 & 0.73 & 31,5 & $\mathrm{E}$ \\
\hline 2019 & & & 5.685 & 2.106 & 0,37 & 49,50 & $\mathrm{E}$ \\
\hline 2020 & & & 5.685 & 2.180 & 0,38 & 49,00 & $\mathrm{E}$ \\
\hline 2021 & $4 / 2 \mathrm{UD}$ & 3 & 5.685 & 2.256 & 0,40 & 48,50 & E \\
\hline 2022 & & & 5.685 & 2.335 & 0,41 & 48,00 & E \\
\hline 2023 & & & 5.685 & 2.417 & 0,43 & 47,50 & E \\
\hline 2024 & & & 6.197 & 2.501 & 0,40 & 52,00 & $\mathrm{D}$ \\
\hline 2025 & & & 6.197 & 2.589 & 0,42 & 51,50 & $\mathrm{D}$ \\
\hline 2026 & $4 / 2 \mathrm{UD}$ & 4 & 6.197 & 2.680 & 0,43 & 51,00 & $\mathrm{D}$ \\
\hline 2027 & & & 6.197 & 2.773 & 0,45 & 50,50 & $\mathrm{D}$ \\
\hline 2028 & & & 6.197 & 2.870 & 0,46 & 50,00 & $\mathrm{D}$ \\
\hline 2029 & & & 3.450 & 1.226 & 0,36 & 57,50 & $\mathrm{D}$ \\
\hline 2030 & & & 3.450 & 1.269 & 0,37 & 57,00 & $\mathrm{D}$ \\
\hline 2031 & $4 / 2 \mathrm{D}$ & 4 & 3.450 & 1.313 & 0,38 & 56,50 & $\mathrm{D}$ \\
\hline 2032 & (Arah 1) & & 3.450 & 1.359 & 0,39 & 56,00 & $\mathrm{D}$ \\
\hline 2033 & & & 3.450 & 1.407 & 0,41 & 55,50 & $\mathrm{D}$ \\
\hline 2029 & & & 3.450 & 1.745 & 0,51 & 55,00 & D \\
\hline 2030 & & & 3.450 & 1.806 & 0,52 & 54,50 & $\mathrm{D}$ \\
\hline 2031 & $4 / 2 \mathrm{D}$ & 4 & 3.450 & 1.869 & 0,54 & 54,00 & $\mathrm{D}$ \\
\hline 2032 & (Arah 2) & & 3.450 & 1.935 & 0,56 & 53,50 & D \\
\hline 2033 & & & 3.450 & 2.003 & 0,58 & 53,00 & D \\
\hline
\end{tabular}

Hasil rekayasa meningkatkan nilai kapasitas jalan menjadi $6.197 \mathrm{smp} / \mathrm{jam}$. Pelebaran lajur memberikan ruang tambahan bagi para pengendara sehingga kecepatan meningkat menjadi 57,50 $\mathrm{km} / \mathrm{jam}$ dan terus menurun seiring bertambahnya arus lalu lintas menjadi $53,00 \mathrm{~km} / \mathrm{jam}$ di tahun 2033. Berdasarkan Peraturan Menteri Perhubungan Republik Indonesia Nomor : PM 96 tahun 2015 dengan kecepatan kendaraan yang dihasilkan maka tingkat pelayanan jalan masih tetap di tingkat D. Hasil rekayasa tersebut menunjukkan tingkat pelayanan meningkat dari kondisi eksisting sehingga pada masa mendatang kemacetan lalu lintas kota Depok selama umur rencana dapat dikendalikan.

\section{Rekayasa simpang tak bersinyal menjadi simpang bersinyal}

Perumusan yang dipilih sebagai langkah untuk meningkatkan tingkat pelayanan pada simpang tak bersinyal kondisi eksisting ialah merekayasa simpang tak bersinyal menjadi simpang bersinyal.

Rekayasa simpang menjadi bersinyal bertujuan untuk memperkirakan pengaruh penggunaan sinyal terhadap kapasitas dan perilaku lalu lintas jika dibandingkan dengan pengaturan tanpa sinyal atau pengaturan bundaran. Simpang bersinyal juga dapat memberi pengaruh yang cukup kuat dalam mengendalikan perilaku pengguna lalu lintas. Sinyal-sinyal yang terdapat pada simpang bertujuan dalam mengatur fase dari masing-masing pengguna jalan sehingga konflik lalu lintas dapat dicegah. Selain itu, dalam penelitian ini direkayasa 
dengan beberapa kondisi yang optimal agar tingkat pelayanan jalan dapat memenuhi ketentuan yang berlaku pada peraturan manajemen rekayasa lalu lintas.

Perumusan rekayasa lalu lintas berlaku untuk umur rencana selama 15 tahun, dimulai pada tahun 2019 hingga tahun 2033. Rekayasa ini diharapkan sebagai program tindakan yang dapat direkomendasikan untuk mengatasi solusi kemacetan lalu lintas untuk 15 tahun mendatang. Hasil rekayasa simpang seperti disajikan pada Tabel 8.

\begin{tabular}{|c|c|c|c|c|c|}
\hline Talhm & $\begin{array}{l}\text { Kondisis } \\
\text { simprang }\end{array}$ & $\begin{array}{l}\text { Kapasitas } \\
\text { (ampjam) }\end{array}$ & $\begin{array}{c}\text { Anus latio } \\
\text { lintas } \\
\text { (smapjama) }\end{array}$ & $\begin{array}{l}\text { Tundauan } \\
\text { (det) }\end{array}$ & $\begin{array}{l}\text { Tingkat } \\
\text { Pelayanan }\end{array}$ \\
\hline \multicolumn{6}{|c|}{ Jalan Raya Sawangan - Nosantara Raya } \\
\hline 2029 & & 3.900 & 1.745 & 0,00 & A \\
\hline 2030 & Tak & 3.300 & 1.806 & 0,00 & A \\
\hline 2031 & Sobidang & 3,300 & 1.869 & 0,00 & A \\
\hline 2032 & & 3.300 & 1.934 & 0.00 & A \\
\hline 2033 & & 3,300 & 2.002 & 0,00 & A \\
\hline 2029 & & 3300 & 2.155 & 0,00 & A \\
\hline 2030 & Tak & 3.300 & 2.231 & 0,00 & $A$ \\
\hline 2031 & Schidang & 3.300 & 2.309 & 0,00 & $\wedge$ \\
\hline 2032 & & 3,300 & $2.3 \%$ & 0,00 & A \\
\hline 2033 & & 3,300 & 2.473 & 0,00 & A \\
\hline \multicolumn{6}{|c|}{ Jalan Prarnaka - Kalilicin } \\
\hline 2029 & & 2.334 & 1.354 & 29,00 & D \\
\hline 2030 & & 2334 & 1.402 & 30,00 & D \\
\hline 2031 & Sebidang & 2.334 & 1.451 & 31,00 & D \\
\hline 2032 & & 23.34 & 1:501 & 31,00 & D \\
\hline 2033 & & 2.334 & 1.554 & 31,00 & D \\
\hline
\end{tabular}

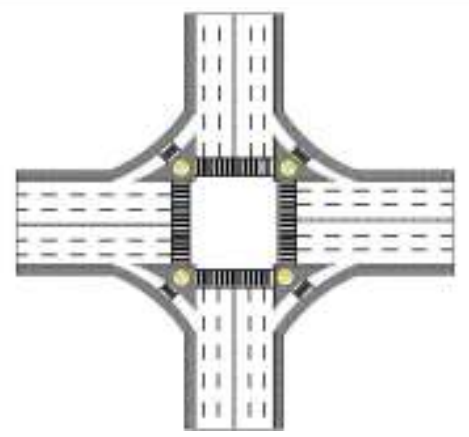

Gambar 8 Simpang jalan bersinyal

Tabel 8 menujukkan bahwa kinerja simpang hasil rekayasa pada tahun 2019 hingga tahun 2028 dengan memperhatikan waktu tundaan yang terjadi. Kondisi simpang direkayasa menjadi bersinyal dengan tujuan dapat meningkatkan nilai kapasitas sehingga waktu tundaan dapat mencapai ketetapan yang berlaku pada Peraturan Menteri Perhubungan Republik Indonesia Nomor : PM 96 tahun 2015. Perbaikan geometri juga dilakukan pada tahap rekayasa ini, yaitu dengan melebarkan jalan menjadi $4 \mathrm{~m}$ per lajur maka total lebar jalan menjadi $16 \mathrm{~m}$ tiap pendekat sehingga tipe jalan menjadi $4 / 2$ UD. Tundaan yang terhitung berdasarkan perhitungan yang terdapat pada MKJI 1997 ialah 32 detik pada tahun 2019 dan terus menurun seiring dengan pertambahan arus lalu lintas sehingga pada tahun 2028 tundaan yang terhitung ialah 80 detik. Berdasarkan nilai tundaan yang terjadi, tingkat pelayanan pada tahun 2019 ialah D untuk 5 tahun pertama (2019-2023) sedangkan pada 5 tahun berikutnya, yaitu pada tahun 2024-2028 mulai melayani penurunan pelayanan pada tahun 2026, yaitu E dan menjadi $\mathrm{F}$ pada tahun 2028.

Tingkat pelayanan yang telah turun menjadi $\mathrm{F}$ menunjukkan bahwa simpang dengan kondisi bersinyal sudah tidak dapat melayani/mampu menerima beban arus lalu lintas yang terjadi sehingga diperlukan rekayasa kembali untuk meningkatkan pelayanan dalam menerima beban arus lalu lintas. Rekayasa yang dipilih untuk meningkatkan pelayanan ialah melakukan rekayasa simpang menjadi tak sebidang.

\section{Rekayasa simpang menjadi simpang tak sebidang}

Persimpangan merupakan bagian yang terpenting dari jalan raya sebab sebagian besar dari efisiensi, kapasitas lalu lintas, kecepatan biaya operasu, waktu perjalanan, keamanan dan kenyamanan akan tergantung pada perencanaan persimpangan tersebut. Skema simpang susun dan kondisi geometri yang direncanakan seperti disajikan pada Gambar 9 dan Tabel 8. 


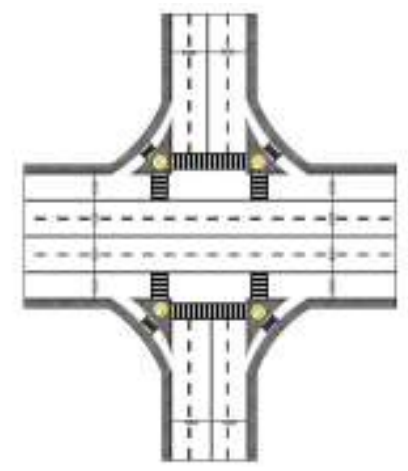

Gambar 9 Simpang jalan tak sebidang

Setiap persimpangan mencakup pergerakan lalu lintas menerus dan lalu lintas yang mendorong pada satu atau lebih dari kaki persimpangan serta mencakup juga pergerakan perputaran. Pergerakan lalu lintas ini dikendalikan berbagai cara, bergantung pada jenis persimpangan. Rekayasa ini diharapkan sebagai program tindakan yang dapat direkomendasikan untuk mengatasi solusi kemacetan lalu lintas untuk 15 tahun mendatang. Hasil rekayasa simpang tak sebidang seperti disajikan pada Tabel 8.

Berdasarkan Tabel 8 menunjukkan bahwa pada tahun 2028 kemampuan simpang dalam melayani beban arus lalu lintas sudah berada di tingkat $\mathrm{F}$ sehingga diperlukan tahap solusi selanjutnya agar umur rencana selama 15 tahun dapat tercapai. Tahap ketiga rekayasa lalu lintas untuk 5 tahun selanjutnya (2029-2033) ialah membangun simpang susun untuk melayani arus lalu lintas yang melewati jalan utama sedangkan jalan minor terlayani melalui simpang bersinyal.

Rekayasa simpang susun diprioritaskan untuk jalan utama, yaitu Jalan Raya Sawangan - Jalan Nusantara Raya sebagai program yang dapat mencegah terjadinya kemacetan di persimpangan tersebut. Hal ini disebabkan arus lalu lintas pada jalan utama untuk kedua arah tersebut lebih besar dibandingkan jalan minor sehingga diharapkan dapat mengurangi konflik lalu lintas akibat beban arus lalu lintas dari jalan utama tersebut.

Target dari rekayasa di tahap ini ialah, kendaraan yang melintas pada pendekat yang lurus dari jalan utama dapat terlayani tanpa mengalami tundaan. Selain itu, kendaraan yang berbelok ke kiri sudah terlayani melalui jalur tersendiri sedangkan kendaraan yang melintas berbelok kanan akan terlayani melalui pergantian fase pada simpang bersinyal. Berdasarkan target tersebut, dilakukan analisis dari kinerja simpang yang direncanakan.

Arus lalu lintas yang mengarah ke jalan Raya Sawangan atau Nusantara Raya terlayani melalui simpang susun ini sehingga para pengendara dapat melaju kendaraannya tanpa mengalami tundaan. Beban arus lalu lintas yang mengarah ke jalan Pramuka atau Jalan Kalilicin maupun kendaraan yang akan melintas berbelok ke kanan akan terlayani melalui simpang bersinyal.

Tabel 29 menunjukkan bahwa kinerja simpang bersinyal dalam melayani beban arus lalu lintas dari masing-masing jalan utama dan jalan minor. Hasil perencanaan simpang susun bagi jalan utama menghasilkan tundaan, yaitu 0,00 detik sehingga berdasarkan Peraturan Menteri Perhubungan Republik Indonesia Nomor : PM 96 tahun 2015 dengan waktu tundaan nol termasuk dalam tingkat pelayanan A. Tingkat pelayanan tersebut menunjukkan simpang tersebut sangat baik dalam pelayanannya karena kendaraan tidak mengalami tundaan untuk melaju kendaraannya.

Hasil perencanaan simpang bersinyal bagi jalan minor menghasilkan tundaan pada tahun 2029, yaitu 29 detik dan terus mengalami perlambatan seiring dengan bertambahnya arus lalu lintas menjadi 31 detik di tahun 2023. Berdasarkan nilai tundaan tersebut, sesuai dengan Peraturan Menteri Perhubungan Republik Indonesia Nomor : PM 96 tahun 2015 termasuk dalam tingkat pelayanan D. Hasil rekayasa tersebut menunjukkan tingkat pelayanan meningkat dari kondisi eksisting sehingga pada masa mendatang kemacetan lalu lintas kota Depok selama umur rencana dapat dikendalikan. 


\section{SIMPULAN DAN SARAN}

\section{Simpulan}

Dilakukan tinjauan terhadap kondisi segmen jalan dan simpang yang terdapat di ruas Jalan Raya Sawangan kota Depok. Berdasarkan analisis terhadap kinerja Jalan Raya Sawanagan, dapat disimpulkan bahwa :

1. Jalan Raya Sawangan memiliki kondisi geometri, seperti tipe jalan 2/2UD, memiliki lebar lajur yang berbeda dari tiap segmen, yaitu 4,2 $\mathrm{m}$ dan 3,5 $\mathrm{m}$. Jalan menggunakan kereb sebagai pembatas antara badan jalan dengan trotoar. Simpang merupakan jenis sebidang tak bersinyal dengan 4 lengan dan memiliki lebar jalur yang berbeda-beda dari tiap lengan. Kondisi lalu lintas, seperti arus total pada jam puncak pagi mencapai 2.671 smp/jam di segmen 1 sedangkan di segmen 2 sebanyak $2.035 \mathrm{smp} / \mathrm{jam}$. Kondisi lalu lintas pada simpang mengalami arus total pada jam puncak sebesar $11.890 \mathrm{smp} / \mathrm{jam}$ dan arus total pada jam puncak pagi merupakan arus total yang jumlahnya lebih besar dibanding jam puncak siang dan sore.

2. Kinerja jalan di segmen 1 pada kondisi eksisting berdasarkan perhitungan MKJI 1997 memiliki kapasitas sebesar 2.912 smp/jam dan kecepatan $28 \mathrm{~km} / \mathrm{jam}$. Sedangkan hasil pemodelan matematis Greenshield menunjukkan kinerja jalan memiliki kapasitas sebesar $2.897 \mathrm{smp} / \mathrm{jam}$ dan kecepatan 17,73 $\mathrm{km} / \mathrm{jam}$. Kinerja jalan di segmen 2 pada kondisi eksisting berdasarkan perhitungan MKJI 1997 memiliki kapasitas sebesar 3.014 smp/jam dan kecepatan 31,5 km/jam. Sedangkan hasil pemodelan matematis Greenshield menunjukkan kinerja jalan memiliki kapasitas sebesar $1.992 \mathrm{smp} / \mathrm{jam}$ dan kecepatan $18,87 \mathrm{~km} / \mathrm{jam}$.

3. Kinerja simpang tak bersinyal memiliki kapasitas sebesar $3.446 \mathrm{smp} / \mathrm{jam}$, tundaan 3,52. Hasil analisis menunjukkan bahwa kinerja jalan segmen 1 dan 2 maupun simpang termasuk jalan dengan tingkat pelayanan di tingkat F. Kondisi tersebut memiliki karakteristik jalan dengan kepadatan lalu lintas sangat tinggi serta volume rendah sehingga terjadi kemacetan untuk durasi yang lama. Kinerja jalan pada kondisi eksisting menunjukkan tingkat pelayanan yang cenderung buruk.

4. Kemacetan yang terjadi pada ruas jalan Raya Sawangan disebabkan beberapa faktor, yaitu beban arus lalu lintas yang besar dan hambatan samping yang tinggi sehingga memengaruhi kecepatan kendaraan, juga karena kinerja simpang yang sudah tidak dapat melayani beban arus lalu lintas di jam puncak, yang telah melebihi dari kapasitas simpang.

5. Rekayasa lalu lintas dalam meningkatkan kinerja jalan dan simpang dilakukan dengan perbaikan geometri, memberikan median serta mengubah kondisi simpang menjadi bersinyal dan tak sebidang.

6. Hasil rekayasa lalu lintas menunjukkan terjadinya peningkatan kapasitas, kecepatan kendaraan dan mencegah terjadinya konflik. Hasil rekayasa lalu lintas meningkatkan tingkat pelayanan ruas Jalan Raya Sawangan ke tingkat D. Kondisi tersebut memiliki karakteristik jalan dengan kecepatan kendaraan sekurang-kurangnya $50 \mathrm{~km} / \mathrm{jam}$, memiliki kenyamanan yang rendah serta pengemudi memiliki kebebasan dalam menjalankan kendaraannya tetapi terbatas.

\section{DAFTAR PUSTAKA}

Abubakar I, Rachmad B, Alik AA, Surti BH, Ahmad M, Hidayah R. 1995. Menuju Lalu Lintas dan Angkutan Jalan yang Tertib. Jakarta (ID) : Direktorat Jenderal Perhubungan Darat.

Astawa IBM, Citra IPN. 2012. Analisis Dajan

A. 1986. Pengantar Metode Statistik Jilid 1. Jakarta (ID) : LP3S

[DepPU] Departemen Pekerjaan Umum. 1997. Manual Kapasitas Jalan Indonesia (MKJI). Jakarta (ID) : Direktorat Jenderal Bina Marga.

Haqqi R, Marpaung HSM, Sebayang M. Analisis Waktu Tempuh Kendaraan Bermotor dengan Metode Estimasi Instantaneous Model. Jurnal JOM FTEKNIK. 4(2) : 1-8.

Hendarsin SL. 2000. Perencanaan Teknik Jalan Raya. Bandung (ID) : Politeknik Negeri Bandung. 
[KemenHub] Kementrian Perhubungan. 2015. Pedoman Pelaksanaan Kegiatan Manajemen dan Rekayasa Lalu Lintas. Peraturan Menteri Perhubungan Republik Indonesia Nomor : PM 96 Tahun 2015. Jakarta (ID): Kementrian Perhubungan.

[KemenPUPR] Kementerian Pekerjaan Umum dan Perumahan Rakyat. 2017. Manual Desain Perkerasan Jalan Revisi 2017. Jakarta (ID) : Kementerian Pekerjaan Umum dan Perumahan Rakyat.

Khisty CJ, Lall BK. 2005. Dasar Dasar Rekayasa Transportasi Jilid 1. Jakarta (ID) : Erlangga.

Masarrang R, Lintong E, Joice, Waani. 2015. Analisa Kinerja Lalu Lintas Jam Sibuk pada Ruas Jalan Wolter Monginsidi. Jurnal Sipil Statik. 3 (11) : 759-766.

Munawar A. 2004. Manajemen Lalu Lintas Perkotaan. Yogyakarta (ID) : Beta Offset Murray RS. 1988. Seri Buku Schaum Teori dan Soal-Soal. Jakarta (ID) : Erlangga. Palin A, Rumayar ALE, Lintong E. 2013. Analisa Kapasitas dan Tingkat Pelayanan pada Ruas Jalan Wolter Monginsidi Kota Manado. Jurnal Sipil Statik. 1 (9) : 623629.

Putri CE. 2014. Analisis Karakteristik Kecelakaan dan Faktor Penyebab Kecelakaan pada Lokasi Blackspot di Kota Kayu Agung. Jurnal Teknik Sipil dan Lingkungan. 2 (1) : 154-161.

Rauf H. 2015. Analisa Kinerja Lalu Lintas Akibat Besarnya Hambatan Samping
Terhadap Kecepatan dengan

Menggunakan Regresi Linier Berganda (Studi Kasus Ruas Jalan dalam Kota pada Segmen Jalan Lumimuut). Jurnal Sipil Statik. 3(10) : 669-684.

Reswantomo BS. 2007. Identifikasi Kinerja Beberapa Ruas Jalan Raya Utama Menuju Pusat Kota Depok [skripsi]. Depok (ID) : Universitas Indonesia.

Setijadji A. 2006. Studi Kemacetan Lalu Lintas Jalan Kaligawe Kota Semarang [tesis]. Semarang (ID) : Universitas Diponegoro.

Sinulingga BD. 1999. Pembangunan Kota Tinjauan Regional dan Lokal. Jakarta (ID) : Pustaka Sinar Harapan.

Sukirman S. 1999. Perkerasan Lentur Jalan Raya. Bandung (ID) : Nova.

Supranto J. 2000. Statistik Teori dan Aplikasi Jilid 1. Jakarta (ID) : Erlangga. Suwardjoko W. 1985. Rekayasa Lalu Lintas. Jakarta (ID) : Bharata Karya Aksara.

Tamin OZ. 2000. Perencanaan dan Pemodelan Transportasi. Bandung (ID) : ITB Press.

Wahab W, Sentosa L, Sebayang M. 2015. Analisis Nilai Pertumbuhan Lalu Lintas dan Perkiraan Volume Lalu Lintas Di Masa Mendatang Berdasarkan Volume Lalu Lintas Harian Rata-Rata. Jurnal JOM FTEKIK . 2 (1) : 1-1 